$\left[\begin{array}{ll}0 & k \\ 3 & 25 \\ D & 3\end{array}\right]$

UC-NRLF

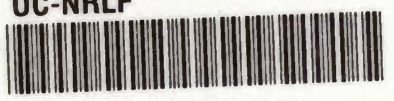

B 4314796 


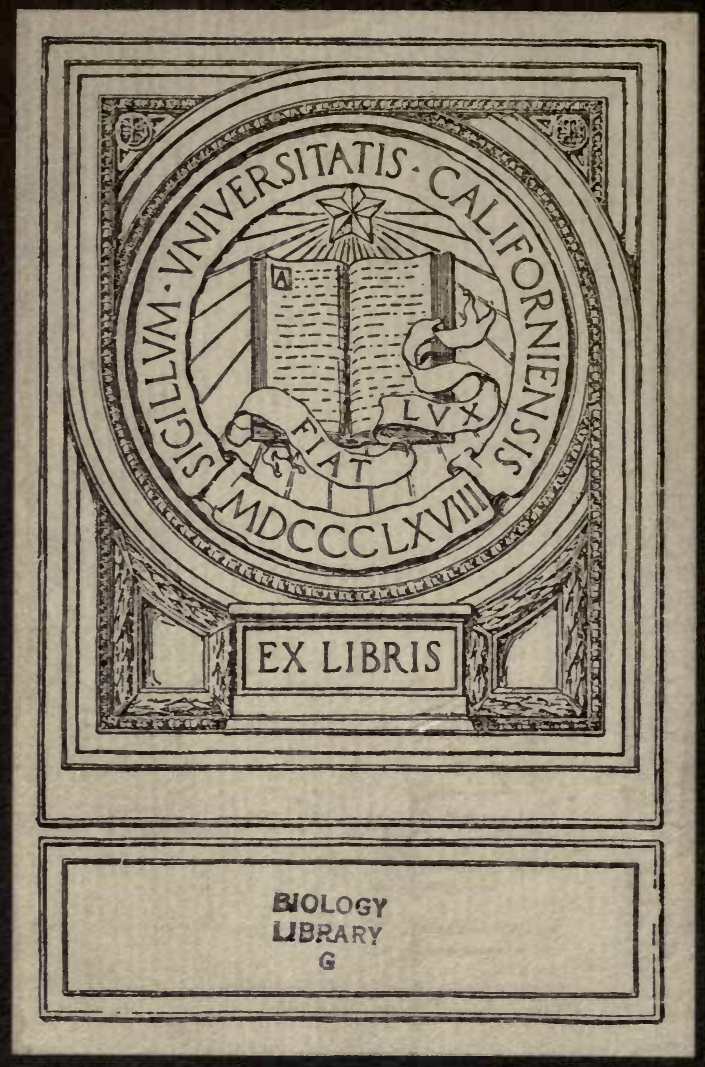

2061 ' 12 mpr IVd

- $\mathrm{X}$. N 'כanjeis SIO्यरा

-sorg proIkso

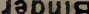

lopydured 


\section{DESCRIPTIVE NOTES}

ON THE TOPOGRAPHY AND VEGETATION OF SOME LOCALITIES VISITED BY THE EXCURSION IN DENMARK ARRANGED FOR THE MEMBERS OF L'ASSOCIATION

INTERNATIONALE DES BOTANISTES

JUNE $22^{\text {nd }}-J U L Y 3^{\text {rd }} 1913$.

EDITED

BY THE

DANSK BOTANISK FORENING.

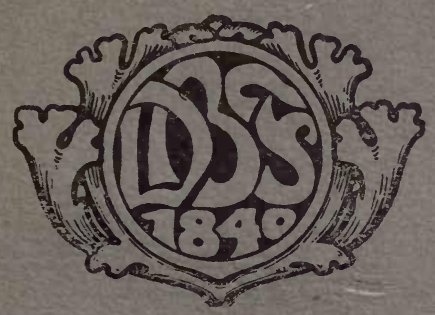

DANSK BOTANISK FORENINGS FORLAG KøBENHAVN 1913 
ओ आ

Epohange 
BIOLOGY

LIBRARY

G

\section{DESCRIPTIVE NOTES}

ON THE TOPOGRAPHY AND VEGETATION OF SOME LOCALITIES VISITED BY THE EXCURSION IN DENMARK ARRANGED FOR THE MEMBERS OF L'ASSOCIATION INTERNATIONALE DES BOTANISTES, JUNE $22^{\text {nd }}-$ JULY $3^{\text {rd }} 1913$.

EDITED BY THE

DANSK BOTANISK FORENING.

\section{A Geological Sketch of Denmark.}

Denmark is a young country. It is true that in the island of Bornholm, Archean rocks and Cambro-silurian as well as Rhætico-liassic formations occur, but in the rest of Denmark the Senonian and Danian stages of the Cretaceous system are the oldest known. A deposit of chalk, hundreds of metres thick, supports the younger formations. It lies directly under the drift in the most northern Jutland and in the south-eastern parts of the Danish islands. In the rest of Denmark it is overlaid by Danian limestones and Tertiary deposits.

As a rule these formations occur in regular, horizontal layers, but in the cliffs of Møen the strata of the chalk are inclined and bent, and numerous displacements along vertical and sloping thrust-planes have destroyed the original connection of the strata and pushed chalk-layers over the till and interglacial sand which originally formed the surface of the country, so that these young deposits now occur between the chalk-layers; at such places brooks have eroded picturesque gullies.

The Danish Tertiary deposits are clays and sands. In the vicinity of Silkeborg especially, Miocene brown-coal is found. Where this is closely examined, it is found to pass downwards into a freshwater-mud, which proves that the brown-coal is autochtone and deposited in freshwater-basins. Plant-fossils are found both in the brown-coal and in the mud. The brown-coal hitherto found has not been valuable enough to pay exploitation.

Of the deposits of the Ice Age till (boulder clay) is the most important. It forms the greater part of the surface of the islands and of the 
land on the eastern side of Jutland, south of the Limfjord, as well as in the western part of this arm of the sea, and as a result these districts are the most fertile of Denmark. Moraine sand forms a great part of the surface in a girdle extending from the frontier through Central Jutland into Vendsyssel, as well as in the "hill-islands " in West Jutland.

Stratified gravel, sand and clay frequently occur over, under and between the moraine deposits. In the islands and in East Jutland they are most commonly covered by till, in West Jutland they not only form the large »heath-plains ", but also appear in the surface of the hills. By far the greater part of these stratified deposits are glaciofluvial, some of them however are shown by the fossils to be interglacial. In some localities in East Jutland (e. g. Fredericia, and Hollerup near Langaa) interglacial lacustrine marls and diatom-earth are found, while interglacial peat-bogs occur at Brørup, Høllund Sogaard, and other places between Kolding and Esbjerg. The interglacial flora is characterized by Picea excelsa, Carpinus betulus, Brasenia purpurea, and Dulichium spathaceum.

The sheath-plain " (Hedeslette), the »hill-land (Bakkeland), and the moraine-flat (Moræneflade) are the principal topographical types of the drift.

The heath-plains are leached plains with very gentle, regular slopes. They consist of glacio-fluvial sands with almost horizontal stratification. The sand, whose original content of lime has been washed out, is infertile. Extensive areas are not yet cultivated. As a rule the vegetation consists only of heath. The heath-plains are interrupted by more hilly areas, known as "hill-islands" (Bakkeøer).

The hill-land is characterized by hillocks and hollows, or by interrupted ridges and troughs, following one another in rapid succession, and without apparent order in their arrangement. The hollows and troughs are often without outlets, and frequently contain marshes, ponds and lakes. Deep gullies and valleys often occur. In the hillland the drift varies, till and moraine-sand predominate, but stratified sand and clay may be frequently still of great importance. 'Then the hills may be heath-clad and form hill-heaths. The most beautiful scenery in Denmark is found in the hill-land, and here grow our woods of native trees.

The moraine-flats may be nearly level, but are more usually gently undulating, the undulations involving long gentle sags and swells, They consist chiefly of till, for which reason the soil is fertile and normally without woods.

These three types of scenery occur in all lowlands which have been covered by an ice-sheet. Their development is caused by phenomena connected with the margin of the ice. The longer this has 


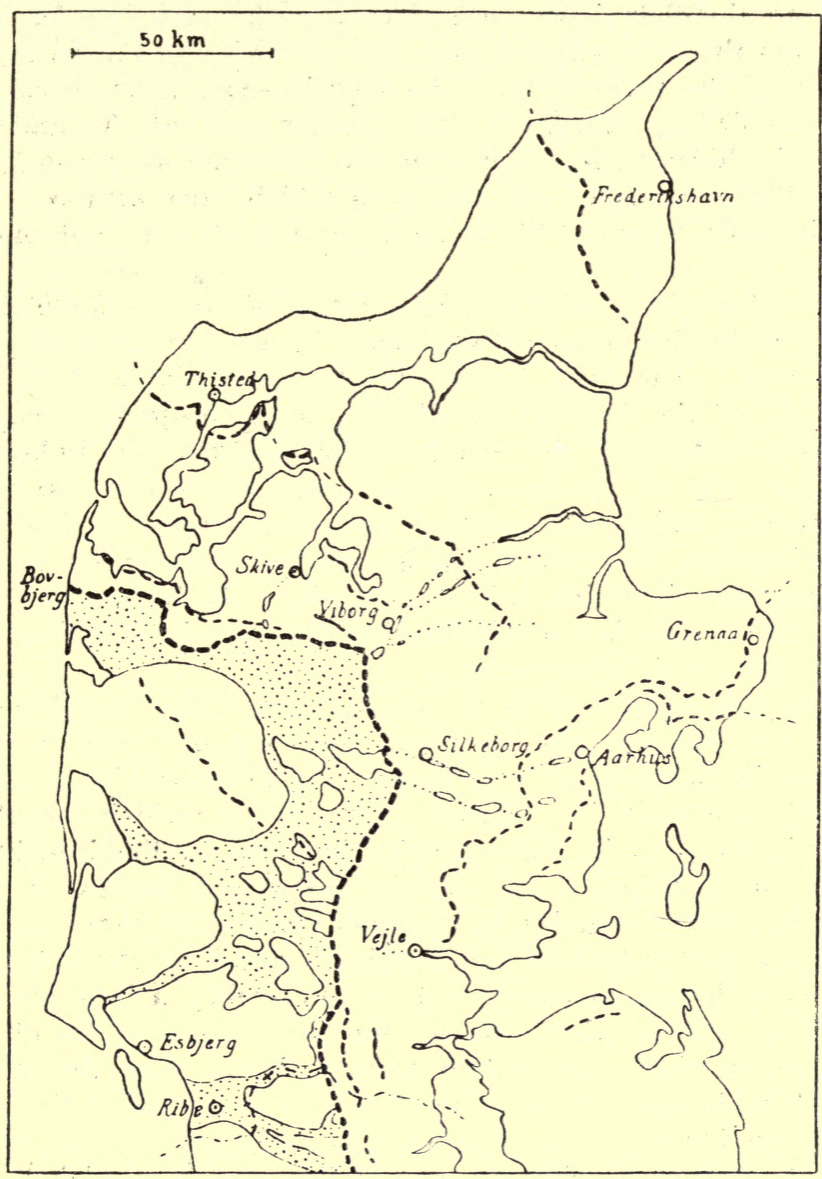

Fig. 1. Jutland peninsula with lines indicating different stages of ice-margins.

remained stationary in any position the more typical the landscapes have become.

The heath-plains are composed of material washed out from the ice by the streams issuing from it and deposited in advance of the ice-margin.

The hill-land was accumulated at the edge of the ice and beneath its margin. Here the ice on melting, gradually left the greater part of the material brought along with it, and here the deposition has been most irregular. 
The moraine-flats have been developed beneath the ice at some distance from the edge where it still was so thick and moved so quickly that it eroded the underlayer. The moraine-flats form broad depressions surrounded by hill-land. The greater part of the material deposited in the hill-land has been removed from the depression, and the relatively thin deposits of till and sand which now compose the surface of the flats have doubtless been formed at the final melting of the ice.

The dotted lines of the map Fig. 1 show in Jutland where the margin of the ice remained stationary in position for a considerable period of time. The thick dotted line indicates (after N. V. Ussing) that position of the ice-edge which has been of greatest importance for the development of the topographical features of Jutland. The dotted areas west of the line are the large heath-plains surrounding the hill-islands, which are parts of hill-land, formed during the preceding ice-invasion, and whose topography has become less rough during the long epoch which has elapsed since its formation. East of the thick dotted line is the hill-land of the last ice-invasion with its still fresh and rough topography.

The present water-courses of Denmark are rather insignificant, but in the Ice Age this was not the case. Then the precipitation of extensive regions in Scandinavia was brought to Denmark in the shape of ice, and the melting ice formed large rivers which eroded considerable river-valleys in the countries in front of the ice-edge (e. g. the valley of Gudenaa). To another valley-type belong the sfjordvalleys «. In contradistinction to common valleys they are distinguished by having an uneven bottom and forming a series of connected depressions. Where the sea penetrates into a fjord-valley a long narrow and deep fjord is formed; where the sea has no admittance we often have elongated lakes where the bottom may be lower than the surface of the sea. The longest of these fjord-valleys reach from the Kattegat to the eastern border of the heath-plains (sketched on Fig. 1). Such a valley extends from Aarhus through Brabrandsø ( $s \sigma=$ lake), Ravnsø, Knudsø, Julsø, Borresø, and Thorsø in the environs of Silkeborg. These valleys have been used by the subglacial streams, which deposited the heath-plains, when they escaped from the ice. Some of the lakes in these valleys owe their existence to ice-masses, which were detached from the main ice during its recession and buried by deposits of sand; later when the buried ice-blocks melted, depressions marking their site resulted and these are now filled by lakes.

After the ice had finally left Denmark, the climate continued to be cold for a long time. Considerable masses of clay were washed down into the depressions and formed deposits of Dryas-clay. The interesting discovery has been made, that a climatic oscillation took place during the formation of the Dryas-clay. In several localities a 
layer of mud or marl (the Allerød-layer) occurs in the Dryas-clay, and the plant-remains of this layer indicate, that during its deposition the climate was not so severe as when the clay-layers with arctic plantremains under it and over it were deposited. Quite recently also "muld " from this warmer period has been found, preserved in a singular manner. In the till on the surface of which the mould was formed, masses of ice, detached during the recession of the landice, were buried. They held out for a long time but finally they melted and left hollows in which the Allerød-muld was buried under clay, mud and peat.

Finally, the definite increase of temperature set in, and the peatlayers now formed show us that an immigration of trees took place, first the birch and the aspen, then the fir followed by the oak and lastly the beech.

Victor Madsen.

\section{Fanø.}

Fanø is a sand island formed from marine sand by the help of the wind; probaby it rests on formations of the Ice Age, but this it not known.

Fanø is increasing in extent both at the northern end and towards the east. The former may result perhaps from a slight raising of the land. From the accompanying map (Fig. 2), it 'will be seen that in the northern part 2-3 parallel ridges of dunes have been thrown up, the one outside the other, and in the $\mathrm{N}$. W. there is a very extensive sandy plane, where new ridges are forming.

I. S a n d-d u n e-formation. On the stretch between the hotels and the north-west end, signs of the incipient formation of dunes will be noticed. Here we find first:

1. Triticetum Tritici juncei; which collects the drifting sand (size of the sand grains $0,5->0,25 \mathrm{~mm}$ ).

2. Elymus arenarius and Psamma arenaria migrate on to these low dunes, and build them somewhat higher and form the $\mathrm{h}$ igh $\mathrm{dunes}$. Elymus only occurs nearer the sea, Psamma goes far inland. On the sand between and on the outermost dunes we may find halophytes, such as Cakile maritima, Honckenya peploides, Glaux maritima, Salicornia herbacea, Atriplex hastata. On the naked sand between the dunes small whitish sand heaps will be noticed; these are formed by tunnel-forming insects (species of Bledius and others).

3. Between the tufts of the two high dune-grasses there is some slight protection from the wind and here there is also room for a number of other, especially more delicate plants, such as the following: Airopsis precox, Campanula rotundifolia, Carex arenaria, Cerastium semidecandrum, C. tetrandrum, Corynephorus canescens, Draba verna, 
Eryngium maritimum, Festuca rubra var. arenaria, Galium verum, Hypochoeris radicata, Jasione montana, Koeleria glauca var. intermedia, Lathyrus maritimus, Leontodon auctumnalis, Lotus corniculatus, Phleum arenarium, Sedum acre, Senecio vulgaris var. radiatus, Sonchus arvensis, Teesdalea nudicaulis, Thymus serpyllum, Vicia cracca, Viola tricolor var. arenaria, $V$. canina etc.

The cover gradually becomes denser; more species are added, among others Silene Otites and several dwarf and creeping shrubs, such as

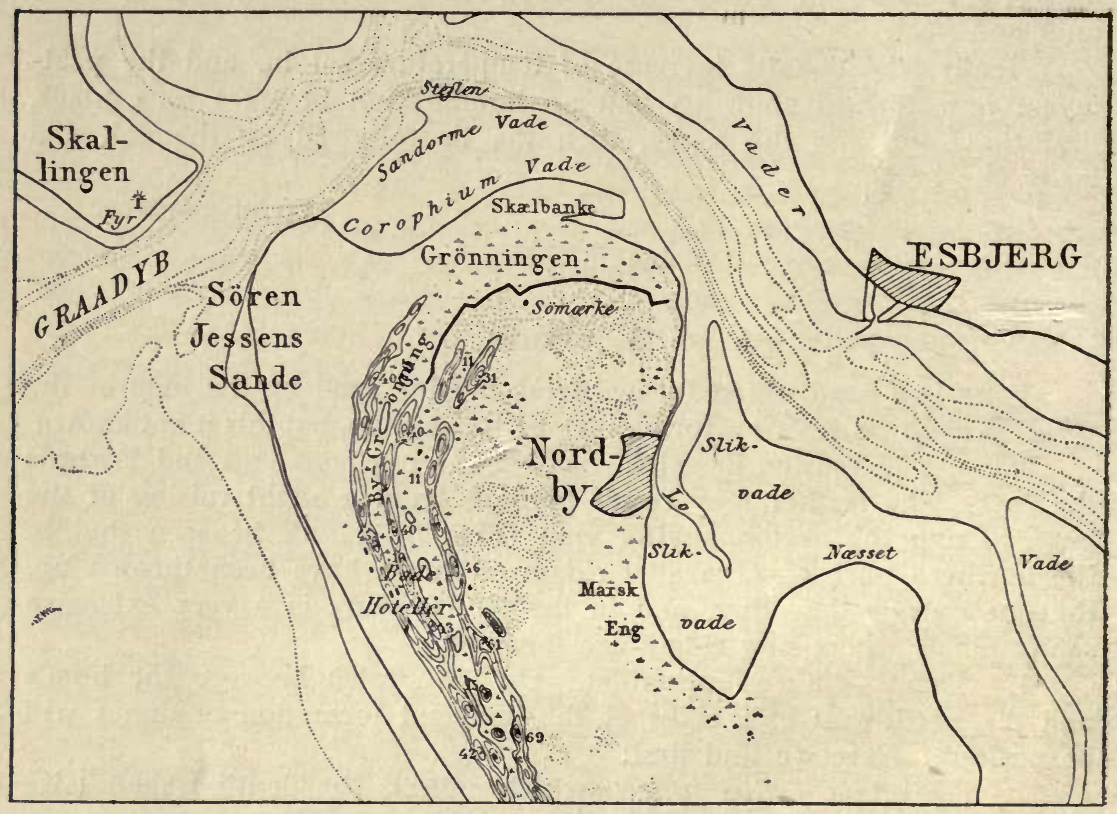

Fig. 2. Northern part of Fanö.

Empetrum, Calluna, Salix repens, Sarothamnus scoparius, Rosa pimpinellifolia etc.

Af $\mathrm{Al} \mathrm{g}$ a e there are very few, but in dark humous sand we may find Zygogonium ericetorum, Gloeocapsa and others. Of I i c h e n s we find a number, especially Cladoniae (C. aculeata, rangiferina, foliacea subsp. alcicornis, uncialis) and Cornicularia aculeata. Of $\mathrm{m}$ os s es there are many, especially Tortula ruralis, Dicranum scoparium, Grimmia ericoides et var. canescens, Hypnum albicans, H. lutescens, H. triquetrum, H. squarrosum etc.

In the hollows between the dunes and on the excavations caused by the wind we may find a number of $\mathrm{f} \mathrm{ungi} \mathrm{(Psilocybe} \mathrm{ammophila,}$ Inocybe maritima, Marasmius oreades and others, often in quantities). 
The "w hite and mobile dunes* are nearest the sea, where the wind brings new sand and often breaks down the already existing dunes. These change, when the vegetation grows more close to $" \mathrm{~g} \mathrm{r}$ a $\mathbf{y}$ d u n e s", with at first a thin, low, often unstable cover, which however is able at last to suppress the high dune grasses.

Several of the herbs, mosses, lichens and dwarf shrubs mentioned may appear in the form of as sociations, and the dunes farther from the sea especially will often show a Calluna association.

II. S a n d y s a l t - $\mathrm{m}$ a $\mathrm{r} \mathrm{s}$. On the north end of the island we have quite a different development. Here we find large sandy flats (æstuaria, Vades, Watten), covered by water at flood-tide, dry at ebb-tide.

1. Outermost is the s a n d-worm flat with thousands of characteristic excrement-heaps formed by Arenicola marina. This worm lives in an U-shaped tube with branches up to $40 \mathrm{~cm}$. long. The entrance is marked by a funnel-like depression caused by the worm ingesting the sand and water; the excrements are expelled at the other opening.

2. In more shallow water live millions of a small crab, Corophium grossipes, which also dwells in U-shaped but much smaller tubes; at flood-tide it emerges from the tube and we can notice its tracks on the sand. Many birds seek their food here on these Corophium-æstuaria.

3. Belt of the s a nd a lga e. This begins in the Corophiumxstuarium but it extends farther inland on botton which is not so often covered by the water. It is especially Myxophyceae of many genera, which bind together the sand grains and form a layer ca. $2-5 \mathrm{~mm}$. thick about $1 \mathrm{~mm}$. below the surface. Many diatoms and some few other algae also live here intermingled and the tunnel-digging insects occur on the drier of these flats.

4. An association of i r o n s u l phide bacte ria forms black masses of sand under the surface.

$\mathrm{N}$ earer the land the flowering plants begin.

5. Farthest out is a Salicornia association ( $\mathrm{S}$ a li c o r n i e $\mathrm{tu} \mathrm{m} S$. herbaceae), very open with blue-green alga bottom.

6. The Glyceria association (G l y c e ri e t u m Gl. maritimae). These species collect the drifting sand and form low tufts.

7. Successively many other plants immigrate, first especially ha$10 \mathrm{phytes}$ and others, such as Cakile maritima, Cochlearia danica, Agrostis alba f. stolonifera, Juncus Gerardi, Glaux maritima, Cochlearia danica, Atriplex hastata, A. patula, Festuca rubra, Honckenya peploides, Matricaria inodora, Odontites rubra, Plantago coronopus, P. maritima, Potentilla anserina, Sagina maritima, Spergularia salina, Triglochin maritimum, Trifolium fragiferum, T. repens etc. Gradually a low, dense carpet is formed on the sand, a marshy meadow, a s and $\mathrm{m}$ a $\mathrm{r} \mathbf{s}$, which affords nourishment to the cows of Nordby.

Many other, less halophilous plants, herbs and mosses, occur on 
the older and higher ground, the earlier associations being gradually crowded out. Many ant heaps. Transitional stages in the formations occur.

III. C 1 a y e $y \mathrm{~s}$ a $1 \mathrm{t}-\mathrm{m}$ a $\mathrm{r} \mathrm{s}$. In the bay east and south of Nordby and at other places on the east coast of Fanø, where the water is calmer than on the west and north coasts, the fine particles of clay and organic material suspended in the water fall to the bottom, the plants lending great assistance. Here extensive banks of mud are formed, »mud flats ( $\mathrm{S} l \mathrm{ik}-\mathrm{V}$ a d e $\mathrm{r} \ll)$; an excellent example is seen south of Nordby.

1. Zostera association, $\mathrm{Z}$ os $\mathrm{t}$ e $\mathrm{r} \mathrm{t} \mathrm{u} \mathrm{m} \mathrm{Z}$. marinae. These soft muddy flats are covered by large masses of narrow-leaved Zostera marina. During flood-tide the long leaves entrap the mud, which is further fixed by the blue-green algae. We also find Zostera minor, Ruppia maritima and Zannichellia.

2. Salicornia as sociation. Where the ground becomes higher we find Salicornia herbacea, which continues the work of trapping the mud during flood-tide. Among its erect, stiff plants live many small snails (Hydrobia etc.) which cover the bottom with their excrements.

3. Where the ground is still higher we find Gly ce rie $t \mathbf{u m ~} G$. maritima, forming a soft grassy turf, in which other flowering plants appear further inland (Aster Tripolium, Atriplex hastata, Glaux maritima, Glyceria distans, Juncus Gerardi, Plantago maritima, Spergularia marina, Sp. salina, Triglochin naritimum, Limonium vulgare).

4. On higher and drier ground we find: Armeria maritima, Artemisia maritima. Festuca rubra, Odontites rubra f. littoralis, Potentilla anserina, Scirpus compressus, Sc. rufus etc.

In the stiff clay soil the flood-tide forms deep, often river-like channels. Characteristic of the marshy meadows are the many holes formed in it.

By means of ditches the inhabitants strive to add to the land. In these ditches we find the Zostera association in the middle, the Salicornia association marginal and uppermost the Glyceria association.

5. Further west the ground becomes partially covered by drifting sand. The vegetation is principally a F e s tuca-as ociation, Festucetum $F$. rubrae, with Armeria vulgaris and many similar species correlated with the dry ground.

Eug. Warming.

D u n e-he aths. The land inside the sea-dunes of the west coast consists partly of old sand-ridges, partly of plains with remains of travelling dunes. The broad, central part of the island is chiefly covered by heath, but a beginning has now been made there with the planting of pines (Pinus montana); on the north and south ends of the island, that is nearest the villages, the plains and hollows between the ridges 
have long been under cultivation or, in the lowest hollows where there is most moisture, used as hay fields.

Some few low spots are filled with water the whole year round and here we find $a$ hydrophyte formation (Potamogeton natans, P. gramineus, Myriophyllum, Littorella, Lobelia, Helosciadium, inundatum, Scirpus fluitans and others) and a helophyte formation (chiefly of Cyperaceae: Carex rostrata, C. Goodenoughii, Scirpus Tabernaemontani, Heleocharis palustris and $H$. multicaulis; further Polygonum amphibium, Glyceria fluitans, Phragmites, Menyanthes, Comarum and others); then follows as a rule a $\mathrm{C}$ y p e r a c a e marsh. Many hollows are filled with water for a longer or shorter period of the year, but not in the summer time; according to the amount of moisture in the bottom of these they are usually covered either by Littorella uniflora, Heleocharis multicaulis or Aira setacea. Ascending from the dampest spots up to the top of the low dunes, we pass a series of different plant associations, whose position is determined by the requirements of the species composing them with regard to the moisture in the soil; as examples may be mentioned, progressing from moister to drier ground:

1. Littorella association.

2. Heleocharis multicaulis association, with $R a$ nunculus flammula etc.

3. A i r s etacea as ociation.

4. L ow e r C y p r a cea e $\mathrm{m}$ a r s h, especially of Rhynchospora fusca.

5. Higher Cyperacea marsh, especially of Carex Goodenoughii and C. panicea; further Drosera, Potentilla erecta, Lycopodium inundatum.

6. E rica he athe $\mathrm{r}$ mo or: Erica tetralix, Calluna vulgaris, Empetrum nigrum, Vaccinium uliginosum, Genista anglica, Salix repens, Potentilla erecta etc.; here also the rare Carex trinervis.

7. C a llu n a h a $\mathrm{th}$; in addition to Calluna, Salix repens, Empetrum, Genista anglica, Vaccinium uliginosum etc., often also many herbs, most often Festuca ovina, Nardus stricta, Anthoxanthum.

8. Thy mus - Salix-Psam ma dunes.

9. P s a m m d u nes.

Naturally, the extension of the various associations varies according to the greater or less slope of the ground, and where the bottom of the hollows is relatively high, one or several of the associations mentioned are of course wanting; further, we find differences in the associations or belts, which are due in part at least to the influence of man, for example harvesting of hay and heather (Ling) or to grazing: the chamæphytes (small shrubs) of both the Erica and Cal- 
luna heaths have been entirely or partially suppressed for the sake of the herbs, especially the grasses, which - as dominant species replace each other from below upwards as follows: Nardus - Sieglingia - Anthoxanthum. These gradually take the place of the heath, as can be seen especially at the north end of the island.

C. Raunkioer.

\section{Borris Heath.}

The $\mathrm{B}$ or $\mathrm{r}$ is heat h or moor, about 1875 hectares in area, was bought by the Government in 1903 and since then has remained as a preserve, except that the army uses it as a shooting range in AugustSeptember. Geologically it forms a portion of the $S ø n d e r-$ $\mathrm{O} \mathrm{m}$ m e plain and is, like our other uncultivated heath plains, a marked Calluna heath. The level surface, sloping slightly towards the west, is broken only by a few systems of ridges running in the main from N. W. to S. E., inland sand-ridges, which have been piled up on the old heath bottom. Their maximum height is $20-25 \mathrm{~m}$. Several of these ridges have been subjected to a very obvious wind erosion and have assumed different forms according to the condition of stability they were in at the beginning of the erosion (examples $\mathrm{B} I$ æ $\mathrm{s}$ b je r g, M u ldsande, Fillingsand). The lowest parts of the area are filled with moss-bogs or peat already formed, on which the dominant moor plants, Calluna, Erica tetralix, Myrica gale and others have long made themselves at home. As typical examples of such peat bogs may be mentioned the $\mathrm{Lang}$ e d a m bog in the southern part of the moor and $\mathrm{Kildes} ø$ bog in its northern part; both of these bogs have an open lakelet in the centre, which is becoming covered over on the lee side, towards the west, whilst on the windward side, east, there are steep banks of peat, which are constantly being eroded by the waves. The Kildesø bog is formed from a lake, which owed its origin to a sand-ridge ( $\mathrm{S} ø \mathrm{~b} \mathrm{j}$ e $\mathrm{rg}$ e $\mathrm{n}$ e) damming up the outlet of the water. Examination of the peat of this bog down to a depth of $1 / 2 \mathrm{~m}$. revealed no other tree remains except thin twigs of Populus tremula, which may be considered to have come from an aspen scrub, some few remains of which are still to be found at one place on the side of the ridge. The remains of oak and birch, so frequent in the bogs of West Jutland, especially on the Bakkeøer", are here quite wanting and this fact, together with the other, that the surface of the heath is here barren and unsuitable for tree vegetation, makes it probable, that the area has never borne woods like most of the other Jutland heaths, but ever since the Ice Age has had the character of a heather moor.

The above explanation has already indicated, what formations we may expect to find. 
A. Chama ephyte and Nanophanerophyte form a t i o n s.

The Chamaephytes of the heather moor (especially Calluna, Empetrum nigrum, Erica tetralix, Arctostaphylos uva ursi) are dominant, wherever there is not too much moisture, chiefly on the mineral soil, but also on the sufficiently dry peaty ground; on the latter we often find in addition the nanophanerophyte Myrica gale. According to the dominant plant we may divide these formations into:

1. Callunetum.

2. Ericetum.

3. Myricetum.

4. Mixed formations (especially Calluna-Empetrum heath and Calluna-Erica heath).

The Callunetum. According to the dampness, richness and exposure of the ground Calluna assumes a very variable appearance, and the age of the crop makes a distinct mark on the physiognomy. Young communities form fresh, brownish green carpets, but soon the growth becomes open and tufty, Cladonia rangiferina is added, and thus, by contrast also with the pale colour of the old heather stems, the brown colour of the older Callunetum becomes spotted with gray. Often we meet with a very open Calluna heath on high and dry ground with sparsely covered sandy spots between the tufts of heather; the first immigrants on sand of this kind (formed by heath fires, gusts of wind or the like) are Polytrichum pilosum and lichens (Lecidea decolorans, Cetraria islandica); later we often find a community of grasses and sedges (Aira flexuosa, Festuca ovina, Weingärtneria, Carex arenaria and others) with their accompanying plants and gradually the Chamaephytes arrive. At many places, especially on the slopes of the ridges, the Callunetum assumes a yellowish-green tone from abundance of mixed and even predominating Empetrum; at places Arctostaphylos forms dense mats, or Vaccinium vitis idaea becomes very prominent. As commoner, accompanying plants in the dry Callunetum, in addition to the above species, we may note: Antennaria dioeca, Arnica montana, Carex panicea, C. pilulifera, Genista anglica, Hieracium pilosella, H. umbellatum, Juncus squarrosus, Nardus stricta, Potentilla erecta, Salix repens, Solidago virga aurea; Stereodon ericetorum often forms a dense mat under the heather tufts. - On stony, wind-swept ground the heather shows only a paltry growth, whereas on peaty soil it forms very strong tufts up to a metre high; on such spots it is mixed with Erica tetralix, and other accompanying plants are also added to some extent: Andromeda polifolia, Eriophorum polystachyum, E. vaginatum, Juncus species, Molinia coerulea, Myrica gale, Oxycoccus paluster, Scirpus caespitosus; Leucobryum and other mosses, especially tufts of Sphagnum. 
The Ericetum is found on somewhat wetter ground than the Calluna formation; here also as a rule much Cladonia rangiferina is intermixed. The accompanying plants just mentioned from the Calluna moor are also characteristic of the Erica moor. The Erica formation finely developed is often seen as a belt round about the bogs, the ground nearest these becoming too wet for Calluna. Mixed formations of Calluna and Erica are frequent. The heather moor, where Erica is dominant, is often visible from a long distance owing to the fact, that Scirpus caespitosus, Juncus species, Eriophorum, Molinia and

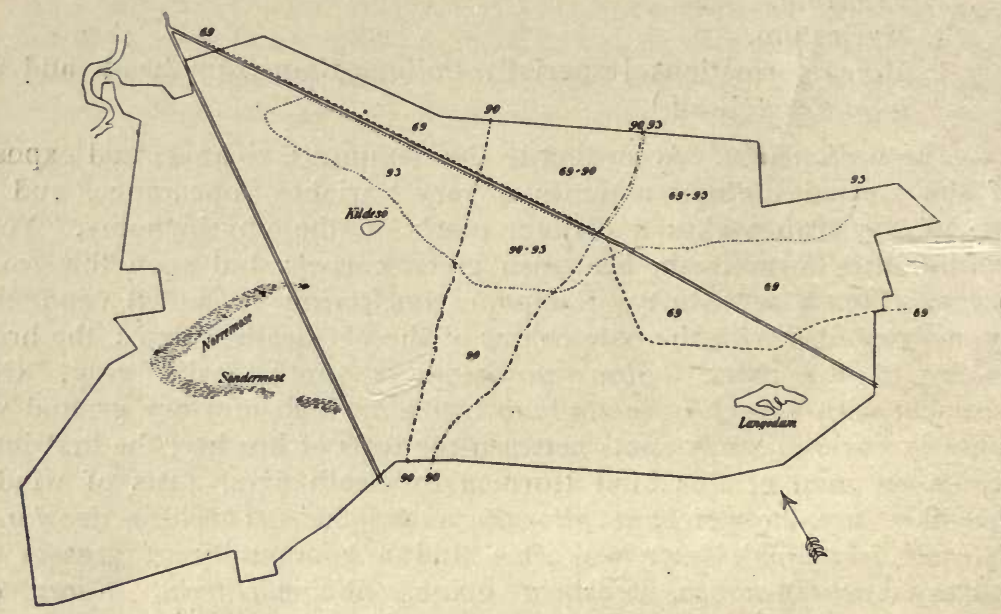

Fig. 3. Sketch of Borris heath indicating the boundaries of different fires. The arrow shows the orientation. In the north-west corner is seen a part of Skjern Aa (river) near the village of Borris. The boundaries of the different fires are indicated by different dotted lines, as also by figures; e. g. 69, 90, 93 etc. indicate the areas burnt in the years $1869,1890,1893 ; 90-93$ thus means the area burnt in the years 1890 and 1893 and so on.

other glumiflores are present in quantities and give the formation a light, yellowish green appearance.

The Myricetum. At some places on the moor Myrica gale forms dense, metre-high communities on old peaty soil; it may appear almośt pure or mixed with Erica, Calluna and the species mentioned above under the Calluna moor.

B. The formation of mosses and helophytes
connected with the water.

Scattered about the heather moor, especially towards the south, we find basins which contain water, at any rate for a great part of the year. 
As a rule mosses cover the bottom of the basin, various species according to the height of the water; usually there is a covering of helophytic phanerogams, which may be very numerous at the margin: Agrostis canina, Carex Goodenoughii, Eriophorum polystachyum, E. vaginatum, Juncus filiformis, J. lamprocarpus, J. supinus, Rhyncospora alba, Scirpus paluster and others. According to the degree of moisture these moss-bogs may be divided into: Sphagnum bogs (Sph. cuspidatum and others), Dicranum bogs (D. scoparium var.), Grimmia bogs (G. hypnoides), Polytrichum bogs (P. gracile) and Stereodon bogs ( $S$. imponens).

In the Sphagnum bogs there may be water over the moss till late in the summer, whilst the other bogs very soon dry up and are only filled with water in the autumn and winter. A zonal formation of the mosses mentioned - according to the degree of moisture - can be observed in the same bog. A later stage of the development may be represented by the Agrostis canina bog and the sedge bog, these plants . dominating over the mosses.

Common to all the formations on the heather moor is their acidophilous character; under the heath, the moor and the true peat the sand can be differentiated into Blysand and Al (moorpan) owing to the action of reducing humous acids.

Lastly, it may be mentioned, that four large heath fires have devastated the heather moor during the past generation $(1869,1890,1893$, 1909); the first and third of these occurred in the dry season of the year and burnt away most of the heath plants, whilst the second and last arose in spring and did less damage. After the last fire the vegetation is still young; the areas burnt in 1869 and 1890 have regained their original appearance, whereas the piece burnt in 1893 still shows a physiognomic difference from the old heath.

\section{Ferdinandsen.}

\section{Knude Moor.}

$\mathrm{Knude} \mathrm{moor} \mathrm{just} \mathrm{to} \mathrm{the} \mathrm{south} \mathrm{of} \mathrm{Herning} \mathrm{is} \mathrm{a} \mathrm{heather} \mathrm{moor,}$ that is, a moor covered with Ericaceae (Erica tetralix and Calluna vulgaris etc.). The actual heather moor is about 380 hectares in area, changing gradually over to grass moor in the east; a small part has been converted into permanent pasture and meadow, but the greater part is still uncultivated, though showing many signs of cultural inroads, in the shape of numerous fires, making of roads, peat digging, ditches etc. The greatest depth of the peat so far measured is $4,7 \mathrm{~m}$.

The vegetation of the still almost undisturbed moor consists of

an Erica-Scirpus-caespitosus-Sphagnum formation. The surface is 
uneven, with elevations built up on Cyperaceae tufts and cushions of Sphagnum and now covered by Ericaceae, and level parts formed of Sphagnum cuspidatum, $S$. recurvum and $S$. tenellum and partially grown over by Eriophorum polystachyum, Rhynchospora alba, Drosera rotundifolia and D. intermedia. Above the level-forming Sphagna come the cushion-forming: Sphagnum papillosum, S. medium and S. rubellum. In and on the cushions we also find: Cephalozia catenulata, Odontoschisma Sphagni, Gymnocybe palustris, Stereodon cupressiformis, S. ericetorum, Hypnum parietinum, Polytrichum commune and others. Of the Cyperaceae Scirpus caespitosus is more abundant than Eriophorum vaginatum, whilst the reverse seems to be the case in other Danish high moors. The tufts are strongest on the boundary of the Sphagnum levels. Among the Ericaceae Erica tetralix on undrained ground is commoner than Calluna, which is more dominant on drier parts. Myrica is more richly represented than is usual in Danish high moors; it reaches its strongest development on the elevations, but likewise wanders out onto the Sphagnum levels. Other accompanying plants are Oxycoccus palustris; Andromeda, Empetrum, Salix repens and Betula pubescens. - On certain parts of the moor, which have probably been less affected by fires, Cladonia rangiferina has a considerable extension; it occurs especially along with cushion-forming Sphagna and on the elevations; here also we have Cladonia uncialis, C. coccifera, C. Floerkeana, C. pyxidata and Lecidea uliginosa.

Cultivation is carried out mainly on the uncut moor. Since 1891 the Danish Heath Society ( Det danske Hedeselskab ) has experimentally reclaimed about 36 hectares and planted about 6 hectares. The method followed has been as a rule the following. The rough moor is drained down to $1^{2} / 3 \mathrm{~m}$. under the original surface. Then the vegetation is burnt off, the largest tufts are cut down and all is levelled with the earth from the ditches. After adding 500 to $100 \mathrm{~kg}$. of $\mathrm{CaO}$ per hectare the ground is left untouched for 1 to 2 years. Then a layer of clay $2.5-4 \mathrm{~cm}$. thick is added; further about $36 \mathrm{~m}^{3}$ of clay marl (with 25 to $30 \%$ chalk) per hectare, which corresponds to 6000 to $9000 \mathrm{~kg}$. CaO per hectare. After this (in the month of March) $180 \mathrm{~kg}$. of $37 \%$ potash manure and $270 \mathrm{~kg}$. phosphates are added, for meadow; smaller quantities for pasture. Nitrogenous manure is not given, but in general a compost is added. The moor is afterwards worked over with the disc-harrow (March-April) and a light harrow. In the same year experiments are made with Leguminosae (peas and vetches). The disc-harrow is used again in the autumn and following spring. This year the ground is laid out for grass: grass and clover seed (with a covering crop, in general oats) covered with the light harrow; the ground is rolled. First and second two years grass crops taken; then grazing. - By means of this comparatively simple and cheap method of cultivation good meadow and pasture lands have been successfully 
obtained. In course of time, however, most of the ground has to be relaid, but one field, used partly as meadow partly as pasture, has been kept as such for 18 years. - At the same time various experiments have been made with regard to quantities of chalk, amount of drainage, seed mixtures etc.

A. Mentz.

\section{Silkeborg.}

Forest and he a $t h$ vegetation. As we pass further from the level country - the large fluvio-glacial sand plains between the low hills ("Bakkeøer") of earlier Ice Age formations - on the way from Herning toSilkeborg, the landscape gradually becomes very uneven; we enter the large glacial marginal formations of the last Ice Period and pass by the great line of the marginal moraine marked on the map (Fig. 1). In the hollows between the heath-covered hills we see low oak shrubs, remnants of the old oak woods, which have gone under in the struggle with man and his domestic animals, poor soil, west wind and the heather. We can picture the course of development. After the ice melted away, the land became covered with a vegetation of low arctic plants (Dryas and others), remains of which are found in the clay layer under the moors and in the deepest layer of these; immigrants gradually arrived, the aspen (Populus tremula) and birch, but the true vegetation of the high wood first began with the pine woods (Pinus silvestris), which were afterwards supplanted by the oak wood, and this again on the good soil of the land had to give way to the beech wood. In West Jutland it is the heather, which in many places has replaced the oak. The pine as a primitive, wild-growing tree has disappeared from Denmark; all the conifer-woods now found here have been planted in the course of the last 150 years, or are descendants from planted trees. The principal Pinus species planted in West Jutland is the mountain pine (Pinus montana), which flourishes well in the windy climate; other plantations are found of the Scotch pine ( $P$. silvestris), but mainly of the common spruce (Picea excelsa). The conifers are spreading especially in Jutland at the expense partly of the beech wood, partly of the heath.

In the environs of Silkeborg the ground-soil is for the most part sand. The sandy hills are covered by beech woods, the wetter hollows chiefly by birch and alder (Alnus glutinosa); woods of conifers also occur.

Eug. W.

In Denmark, which in climatological-pedological respects belongs to the humid regions of Europe, decomposition of the ordinary remains of organic life on high-lying areas (i. e. away from water-basins and 
their developments: swamp and marsh) generally leads to two main forms, »muld (e. p. vegetable mould of Darwin; ordinary humus of Warming) and »mor" (raw-humus of German terminology).

The $\mathrm{muld}$ " consists of the mineral soil in intimate mixture with remains of plants and animals in various degrees of decomposition. The mixing is carried on in nature mainly by animals, especially earthworms; the organic refuse is quickly decomposed (in the woods as a rule in the course of a year) and the decomposition is effected in the main by bacteria, which by energetic cellulose fermentation and subdivision of the peptones rapidly brings the constituents of the refuse masses inlo circulation again. The nitrogenous compounds are decomposed under development of nitric acid. The natural muld soil has an aggregate structure (gritty) and is loosely deposited, thus easily permeable by air and water; it reacts neutral, faintly acid or faintly alkaline.

The phanerogamic vegetation on this soil varies according to the warmth and light of the place, the moisture of the soil and its content of assimilable mineral constituents. -

The "mor" is formed, when the organic refuse is deposited above the mineral soil, the fusion element, the animal life, being absent or where the latter for various reasons is unable to carry out the mixing of the soil and the humous elements with sufficient energy. In the decomposition, humifaction, of the organic refuse above the soil the fungi play a prominent part, the bacteria a more subordinate role. Decomposition proceeds slowly, extending often over many decades, and during this process large quantities of humic acids are deyeloped (colloidal, non-absorptive saturated humous materials). On being carried down into the mineral soil by rain-water, these "acids" withdraw from the soil's uppermost layer a large quantity of decomposable mineral compounds (iron salts, hydrate of lime, alkalies and alkaline earths etc.), which by absorption are deposited at some distance from the surface and may give rise to the formation of hardpan. Even the uppermost humus layer has a variable texture, from loose deposits to a very dense and firm felt; the washed-out layer under the "mor " is always dense with very small porous capacity ("pore-volume*); the hardpan layer may vary from being earthy and loose to a perfectly dense and firm, stone-hard layer, impermeable by plant roots, with its single grains fused together by colloidal, humic compounds. The soil always reacts strongly acid. The bacterial vegetation in the »mor *covered areas decreases greatly, both in number of individuals and in virulence, with little ability to decompose cellulose and to split up the peptones, and with reduction or cessation of the development of nitric acid. In further stages of the mor-formation and especially in the old deposits of this kind a considerable portion of the nitrogenous compounds of the organic refuse is fast bound in resistant fungal my- 
celia and is thus withdrawn from circulation, so that this soil in its most distinctive forms - especially the old heaths - only has a small quantity of ammonium compounds, produced mainly by physico-chemical means, to provide the phanerogamic vegetation with nitrogen, and absolutely no nitric acid. The main character of typical "mor " as a soil for vegetation is therefore its poverty in assimilable nitrogen, and its vegetation consists, so far as known, exclusively or almost exclusively of plant-species with endotrophic mycorhiza, which possibly through their assimilation of the nitrogen of the air become independent of the assimilable nitrogenous compounds of the soil (Ericaceae etc., Frank, Stahl).

The phanerogamic vegetation varies on this soil not only according to the same ecological factors as on the "muld «-soil, but likewise according to the different biological conditions set up by the thallophytic vegetation in the ground.

"Muld « and "mor « are therefore the results of biological processes in variable combination with climatic and pedological conditions and the plant-associations react in the most marked degree to the different stages of this interplay.

The old heaths in many parts are probably derived from the post-glacial period of the tundras and where the soil content has been most extracted, the "mor "-formation is carried to its greatest extent with quite dominant fungal decomposition of the vegetative refuse, with extreme reduction of the bacteria life and with almost complete cessation of nitric acid production. It supports especially the Calluna-, Empetrum-and Lichen-heaths. The young heath is better; it was covered for the most part by the glacial mass of the last glacial period and its soil as a rule has suffered less from the extraction of its content. This young heath has in great part been covered by woods, which have been supplanted by Calluna-heaths with Hypnum, Hylocomium and others. Here some formation of nitric acid still occurs in the soil and the vegetation is richer, more varied and with frequent occurrence of remnants of woods.

But even the dominant plant-association of phanerogams has a considerable influence on whether the locality is readily exposed to »mor«-formation or not. The Ericaceae (not only Calluna but the whole series of related forms) affords ready access to malignant "mor " with accompanying transformation of the underlying soil. Of forest trees the beech, especially on dry and sandy soil, is disposed to further the formation of "mor", and the beech association growing on muld soil can during its development change the nature of the soil in such a way, that after a generation "mor " is formed, which hinders the regenerating of even the mother association, a renewal by natural means being excluded. Less exposed to "mor «-formation are Picea- and Abies- 
associations, least or not at all various deciduous trees with light foliage, as the oak.

Silkeborg forest is an example of this. The old Jutlandic oak woods on the sandy soil, which have still been able to withstand the immigration of the heath, have preserved the "muld " character of the soil for thousands of years, for they must be considered as the direct descendants of the extensive oak woods of the post-glacial period before the late immigration of the beech. Even in historical times the woods at Silkeborg have been such oak woods with "muld " soil, into which the beech has immigrated. Now the oak has quite disappeared as a plantassociation from these woods, and the chief natural tree is the beech, which in its ascendency has transformed the smuld of the soil to "mor " and thus produced a condition in the humous ground, which will probably no longer permit the beech wood to renew itself without the interference of man.

P. E. Müller.

\section{Viemose Forest.}

The ground is stiff, usually brownish clay with good mould. The wood consists mostly of oaks (Quercus robur), with a few beeches. It is an old cultivated forest, where the oak has long been grown to obtain timber for shipbuilding and other use. The undergrowth is formed of hazel (Corylus avellana), often changed with beech or elm (Ulnus glabra), maple (Acer pseudoplatanus) and ash. (Other shrubs are: Crataegus, Cornus sanguinea, Evonymus europaeus, Rhamnus frangula, Viburnum Opulus, Rubus idaeus. On the good ground in the ligh! and sheltered surroundings we have a luxuriant vegetation of woodland plants, such as Anemone, Primula, Stellaria nemorum, Actaea, Arum, Paris, Galeobdolon, Asperula, various Orchidacece and others.

Eug. W.

\section{Møens Klint (Chalk cliffs of Møen).}

The Island of $\mathrm{M} ø$ e $\mathrm{n}$ lies to the south of Sealand, separated by sounds from the latter and the island of Falster; its other coasts are washed by the open Baltic. The easternmost part of Møen, sHøje Møen ", forms a part by itself, separated from the remainder by a north to south depression, $\mathrm{B}$ or r e $\mathrm{M}$ os e and $\mathrm{B}$ us s e m a r k Mose, both of which lie only $1-3 \mathrm{~m}$. above the sea. This depression now consists 
of wet meadows and fens with two overgrown small lakes and is of very recent origin; in a late post-glacial period it was a sound and Høje Møen was thus an independent island. Even in historic times the village $B$ or $\mathrm{r}$, which at the present day lies in the centre of the depression $3 \mathrm{~km}$. from the sea, was a port engaged mainly in the herring fishery (in the year 1510 the Lubeck fleet sailed up through the narrow entrance and sacked the town; but in 1648 the complaint was made, that only small boats could reach up to it).

From the Borre depression the land ascends somewhat steeply towards the east in more or less irregular waves and forms the compact mass, which is called $\mathrm{H} ø \mathrm{je} \mathrm{M} ø \mathrm{en}$. The highest points (A borreb j e r g, $143 \mathrm{~m}$., and $\mathrm{K}$ o $\mathrm{ng} \mathrm{s} \mathrm{b} \mathrm{j} \mathrm{e} \mathrm{r} \mathrm{g,} 135 \mathrm{~m}$.) lie close out towards the sea yet inside the coast line, which for almost the whole way consists of steep chalk cliffs broken by deep clefts; the highest points of the cliffs are Dronningestolen (Queen's Seat) and Hylledals $\mathrm{K}$ lin $\mathrm{t}(128 \mathrm{~m}$.). The chalk layers in the cliffs are inclined, bent and much displaced (see Introduction), which is believed to have occurred at a very late period; but the surface of the land is covered by moraine clay and sand, the chalk not appearing on the surface except on the side of the cliffs. The deep clefts ("falls") are filled with moraine deposits, which are also found here and there in streaks and pockets enclosed between the chalk layers. In the clefts and many other places we find freshwater springs and small water-courses, surrounded by a very luxuriant spring-water vegetation. At the base of the cliffs there is a narrow foot (beach), which, however, when the water is high and the wind blowing onshore, is often entirely covered by the waves which break against the cliff. - At many places on Høje Møen there are numerous larger or smaller la nds li p hollow s (pot holes, Jordfaldshuller), which are supposed to have been formed by the gradual dissolving of certain parts inside the chalk by the constant infiltration of water; in this way holes or caves were formed and the roof at last has fallen in. The characteristic hollows thus formed have fairly steep sides and a flat bottom and may be filled with water, the earlier existing outlet having become stopped up. In any case one of the three small lakes on Høje Møen ( $\mathrm{H}$ u n o $\varnothing$, A borresø and $\mathrm{Gjeddesø)}$ has been formed in this way, namely, Aborre Lake. - The greater part of Høje Møen is cultivated land, but considerable stretches of wood also occur (ca. 700 hectares) as well as a certain amount of pasture grassland and the coastal tract.

The plant as s o ciation s on the chalk cliffs of Mren, which are of special interest to botanists, are mainly the following (considering here only the associations which occur (a) above on the surface of the cliffs, (b) on the slopes and (c) on the base at the coast):

1. The cliff wood (Klinteskoven) is a pure beech wood (Fagus association), in which Fagus silvatica is practically the only 
timber tree. A few Prunus avium, P. padus, Sorbus aucuparia, Ulmus glabra ( $U$. montana) and Acer campestre occur singly ${ }^{1}$.

The beech wood is not quite like the ordinary Danish beech woods on muld soil; the rich content of chalk in the ground causing some difference in the flora. We find, namely, various c a l c i p h i l o u s species, which are elsewhere rare in Denmark, such as Epipactis atrorubens (only on Møen's cliff), Cephalanthera rubra, C. grandiflora, Orchis purpureus, O. ustulatus, Anacamptis pyranidalis (the last three mainly outside the true beech wood); also, more frequently and more abundantly than elsewhere, Coralliorhiza, Monotropa, Neottia, Hieracium caesium, Carex digitata, Primula acaulis ( $P$. vulgaris) and Dentaria bulbifera, which however are less bound to the chalk than the previous group.

The specific richness of the Orchidaceae on Møen's cliff is surprisingly great; to those already mentioned should be added Epipogon (extremely rare), Epipactis varians, E. latifolia, Orchis masculus and on marshes and meadows O. latifolius, O. incarnatus, O. maculatus, Epipactis palustris (Aborre Lake), Listera ovata and Herninium monorchis.

Large parts of the wetter and more shaded beech wood are covered by a monotonous Equis e $\mathrm{tum}$ vegetation, Equisetetum $E$. hiemalis, whose sombre colour and constant rustling of the siliceous stems in the wind have a peculiar, gloomy effect.

Apart from these peculiarities the g round vegetation has the usual character plants: Anemone nemorosa, A. ranunculoides, Oxalis acetosella, Mercurialis perennis, Asperula odorata, Lathyrus vernus, Hepatica triloba, Pulmonaria obscura etc. as the s p r in g a s e ct; grasses (Dactylis glomerata subsp. lobata, Bromus asper (B. Benekeni), B. ramosus, Festuca gigantea, Melica, Poa nemoralis, Milium effusum) and various herbs (Sanicula europaca, Circaea lutetiana, C. alpina, Pirola minor, Ramischia secunda and others) as the $\mathrm{s} u \mathrm{~m} \mathrm{~m}$ e $\mathrm{r}$ a s p e t.

The flora of the cliff wood is also famous for the frequently occurring hybrids between $P$. acaulis, $P$, elatior and $P$. officinalis ( $P$. veris), and for several interesting mosses (Hypnum molluscum, Thamnium alopecurum, Encalypta streptocarpa,. Neckera-crispa) and l i c h e n s (Solorina saccata, Collema auriculatum, Leptogium scotinum, Pannaria nigra, Peltigera aphthosa, Sticta herbacea and Urceolaria scruposa).

2. The scrub on the edge and sides of the cliffs forms a variegated plant association or rather several associations; the two most characteristic shrubs are Hippophaës rhamnoides (mostly on the edge of the cliff) and Juniperus communis (on the slopes); but we also find

1 As planted trees at a number of places occur oaks (Quercus robur). Further, coniferous woods occur planted at several places (e. g. Aborrebjerg) mostly of Picea excelsa, more rarely Pinus austriaca and P. strobus. 
in the scrub dwarfed beeches, Crataegus oxyacantha, Prunus spinosa, Lonicera xylosteum (usually on somewhat wet soil), Cornus sanguinea, Acer campestre, Salix species of the Caprea group (wet), as also, special (in Denmark) to Møen's cliff Ribes alpinum and subspontaneous Daphne Laureola. The ground and the stems of the shrubs are sometimes covered by Hedera.

The ground vegetation growing among these shrubs varies to a great extent according to the denseness of the scrub and the wetness and consistency of the soil; the Juniper scrub is the driest and most open, the Salix scrub is wet and the Hippophaës scrub is very dense. The species of the ground vegetation come partly from the ground flora of the beech wood, partly from the associations of the open slopes and lastly, in the wet clefts, from the association of the spring-water vegetation.

The last, the vegetation of the "f a $11 \mathrm{~s}$, is something characteristic of Møen and merits more detailed mention. The beech wood or the scrub like to follow the water trickling down through the clefts ("falls «), the trees and shrubs covering the slopes whilst the bottom of the clefts is filled by the hygrophilous vegetation. This is remarkable for its enormous luxuriance, consisting of a large number of hygrophilous species, of which only the characteristic species of a single "fall" (M a g levandsfald) need be mentioned: Equisetum maximum (in great quantities), E. fluviatile, $E$. arvense f. nemorosa and the hybrid between the last two, Carex paniculata, Scrophularia alata, Juncus glaucus, Cardamine impatiens and Festuca silvatica. The water in the course of the "fall " is cold and rich in chalk; in another fall ( $J \mathrm{y} \mathrm{d} \mathrm{e} \mathrm{l} \mathrm{e} \mathrm{j} \mathrm{e} \mathrm{t)} \mathrm{calcareous} \mathrm{tuff} \mathrm{can} \mathrm{even} \mathrm{be} \mathrm{seen} \mathrm{under} \mathrm{formation.} \mathrm{The}$ fauna in the water-courses of both these wfalls " is characteristic, containing alpine Phryganeae and the remarkable flat-worm Planaria alpina, which is otherwise not known from Denmark and is considered to be a glacial relict.

3. The vegetation of the open slopes. The scrub on the summit of the cliffs leads gradually with decreasing number of shrubs to the open slopes. These harbour on the whole a species-rich plant vegetation, varying greatly according to the nature of the soil, as the latter may vary from pure sand to chalk-rich clay; on the whole the sand is predominant and the vegetation has thus a distinct xerophilous character. Among the more prominent species of perennial herbs occurring in $\mathrm{the} \mathrm{summer}$ a s pet may be named; Silene nutans, Astragalus glycyphyllus, Daucus . carota, Galium verum, Campanula persicifolia, Scabiosa columbaria, Helichrysum arenarium, Artemisia campestris, Senecio Jacobaea, Centaurea scabiosa, Carlina vulgaris, Cirsium acaule, Hieracium umbellatum, Calamintha acinos, Thymus chamaedrys, Origanum vulgare, Rumex auriculatus, Briza media, Avena pratensis, 
Festuca arundinacea, Poa compressa, Cynosurus cristatus, Polygala vulgaris, Fragaria vesca, Linum catharticum, Phleum Boehmeri, Helianthemum chamacistus, Lotus corniculatus, Trifolium arvense, Filipendula hexapetala. In s p ring a quantity of mainly annual species appear on these slopes (a the r o phy tic, s p ring a s p e ct), e.g. species of Myosotis, Erophila verna, Teesdalea, Stenophragma thalianum, Alsine viscosa (only on Møen), Holosteum umbellatum, Cerastium semidecandrum, Aira praecox, A. caryophyllea, Saxifraga tridactylites, and in addition the perennial species Potentilla minor, Saxifraga granulata, Anthoxanthum, Arabis arenosa and others.

On the gradation from scrub to open slope we meet with plants such as Lithospermum officinale, Orchis ustulatus, O. maculatus, $O$. purpureus, Anacamptis, Picris hieracioides, Hypericum montanum, Trifolium pratense (in a specially hairy form), Botrychium Lunaria, Platanthera etc.

The large number of names, to which many others could be added; show best what a variegated plant vegetation occurs both in the scrub and on the open slopes. The ecology of these associations is still but little known; it is to be hoped, that future investigations will lead to a more ecological subdivision, for the present we must be content with the purely physiognomical ${ }^{1}$.

4. The lithophilous vegetation on the chalk cliffs is quite inconsiderable. The steep, bare surface of the cliffs is in general naked and if any vegetation occurs, it is only insignificant algae (e. g. Gongrosira Debaryanum, Stichococcus bacillaris, Trentepohlia aurea, diatoms and a few Myxophyceae) and the small moss Seligeria calcarea. Cracks and fissures are not formed in the comparatively soft chalk and there is thus no place for higher plants (Chomophytes). Where such occur on ledges and slopes, they are only small out-runners from the vegetation of the wood, scrub or slope. Ledges and slopes occur mainly in the lower part of the cliffs and at the foot, produced by the sliding down of the chalk mould.

5. The narrow strand region (sand), which lies off the foot of the cliffs, is usually quite devoid of vegetation. Here and there however, we find a few individuals of a poor s a n d-beach veget a tion such as Cakile, Salsola kali, Atriplex littoralis, A. hastata and more occasional guests, as Tussilago farfarus, Festuca arundinacea etc. -

The number of species of vascular plants on Høje Møen is stated to be 578 (Rostrup). -

Short notes on the vegetation of Møen are to be found in $B$ o $t$ a $n$ is $k$

${ }^{1}$ It has some resemblance to the chalk scrub and grassland associations of South England (cf. Tansley, Types of British Vegetation, pp. 171-181). 
T i d s s k r i f t, vols. 7, 11, 13, 19, 24 and 29; in C. P u g g a a r d, Møens Geologie, Copenhagen 1851 (by $\mathbf{J}$ oh. L a n g e); and in Eug. W a rm i n g, Dansk Plantevækst, I. Strandvegetation, 1906, pp. 24-29. Hitherto, no fuller reports on the vegetation of this beautiful island have appeared.

\section{H. Ostenfeld.}

Some Literature on the vegetation of the localities to be visited in Jutland (Nos. 1-4):

Baagøe, J., og Ravn, F. Kølpin: Exkursionen til jydske Søer og Vandløb. - Botan. Tidsskr., 20. 1896.

Dalgas, E.: Geografiske Billeder fra Heden. Kjøbenhavn 1867-68.

Galløe, O., og Jensen, C.: Plantevæxten paa Borris Hede. Botan. Tidsskr., 27. 1906.

Mentz, A.: Studier over danske Hedeplanters Økologi I og II. Botan. Tidsskr., 27 (1906), 29 (1909).

- Studier over Likenvegetationen paa Heder. Ibid., 23. 1900.

- Træk af Mosvegetationen paa jydske Heder. Ibid., 24. 1902.

- Studier over danske Mosers recente Vegetation. Ibid., 31. 1912.

Müller, P. E.: Studier over Skovjord. - Tidsskr. for Skovbrug, 3 og 7. 1878, 1884.

- Studien über die natürl. Humusformen. Berlin 1887.

- og Weis, F.: Studier over Skov- og Hedejord. III. Det forstl. Forsøgsvasen i Danmark III. 1913.

- og Helms, Johs.: Forsøg med Anvendelse af Kunstgødning til Grankultur i midtjydsk Hedebund. Ibid.

Raunkicer, C.: Vesterhavets Øst- og Sydkysts Vegetation. Festskrift, Borchs Kollegiums 200-Aars Jubilæum. 1889.

Warming, Eug.: Botaniske Exkursioner I og II. Vidensk. Medd., Naturh. Forening, København 1890-1891.

- Exkursioner til Fanø og Blaavand i 1893 og 1899. Botan. Tidsskr. 19 (1893) og 25 (1902).

- Bidrag til Vadernes, Sandenes og Marskens Naturhistorie. Under Medarbejde af C. Wesenberg-Lund o. fl. - K. Danske Vid. Selsk. Skr. 7. R. II. 1904.

- Dansk Plantevækst. I Strandvegetation. II Klitterne. København 1906, 1907-1909.

- Fra det brændte Himmelbjerg. — Botan. Tidsskr., 39 (1913). 


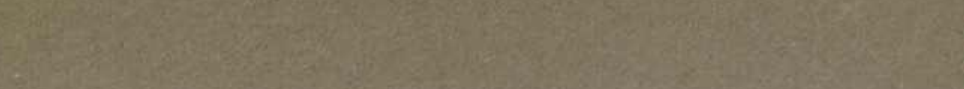

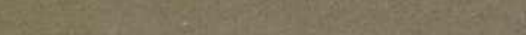

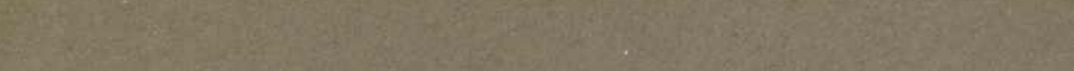
(3)

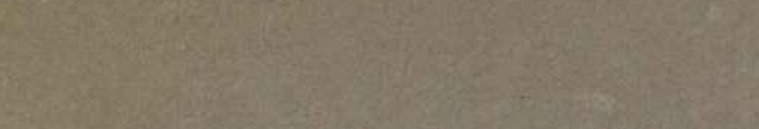

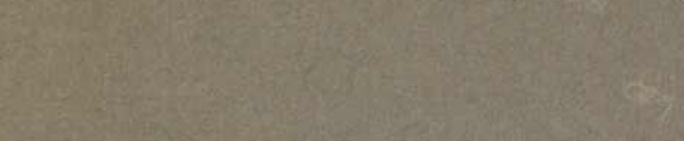

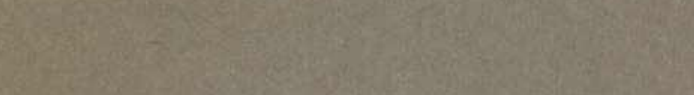

tondsing histing

Qences $\cos ^{2}$ 3. ato

is

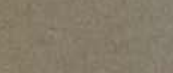

10.

(6.)

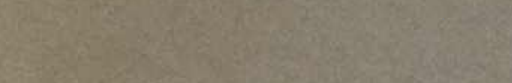

at

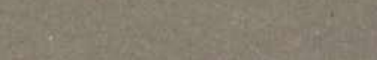

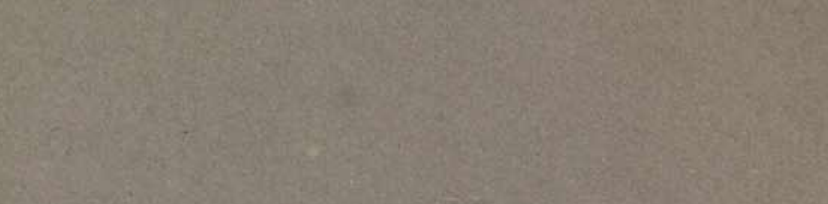

arsis.

esicic

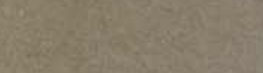

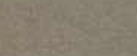

-

2. 8270

26.

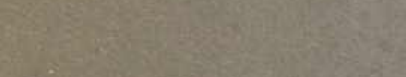
-

(3)

Asting

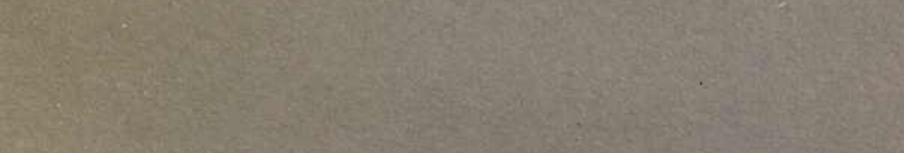

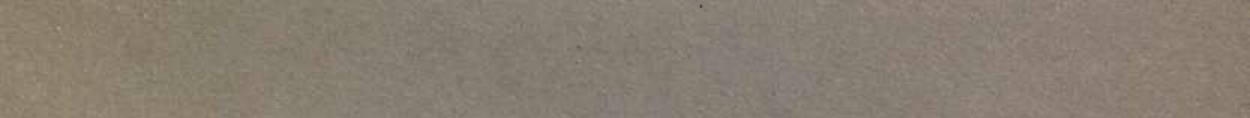

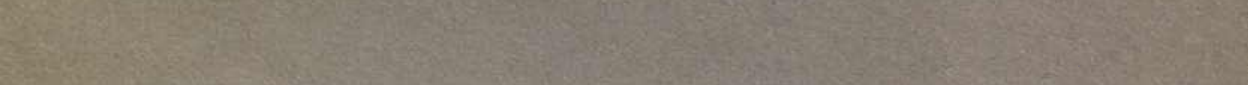
sitis

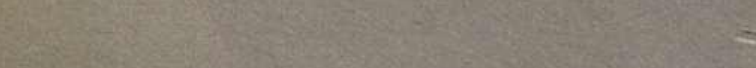

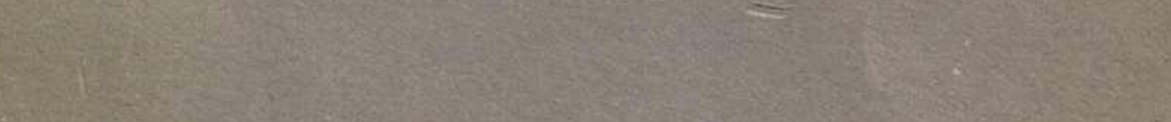
W.

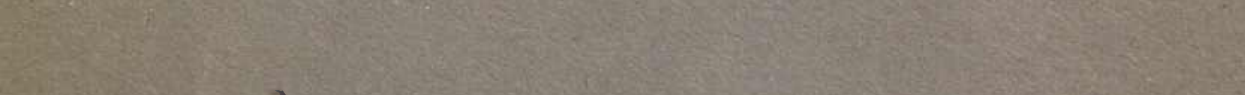

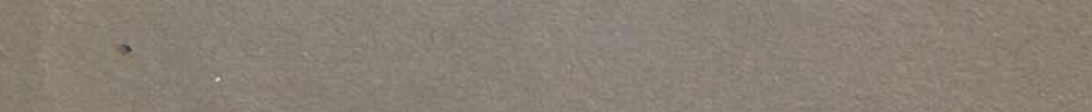

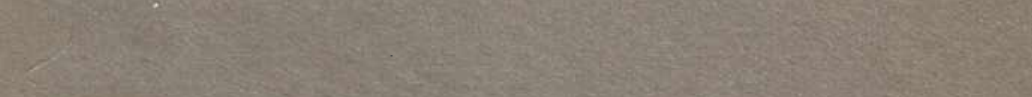
(2)

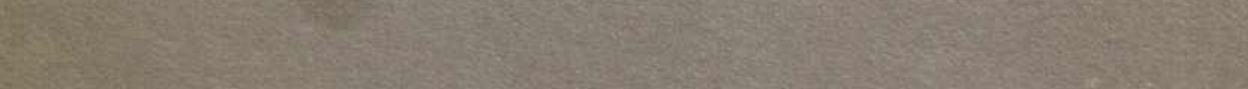

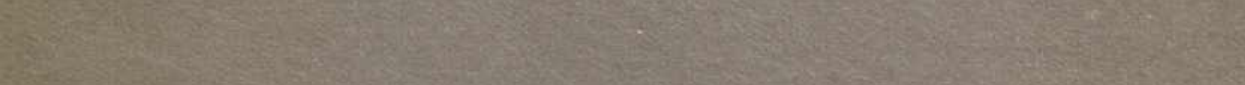

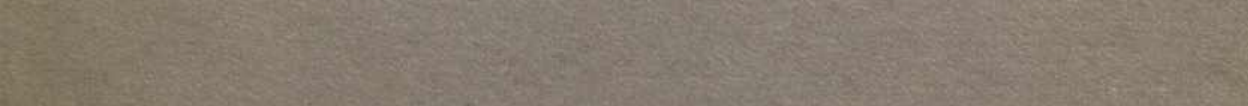

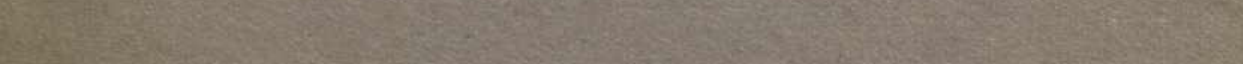
(2) 


\section{UNIVERSITY OF CALIFORNIA LIBRARY, BERKELEY}

THIS BOOK IS DUE ON THE IAST DATE STAMPED BELOW

Books not returned on time are subject to a fine of $50 \mathrm{c}$ per volume after the third day overdue, increasing to $\$ 1.00$ per volume after the sixth day. Books not in demand may be renewed if application is made before expiration of loan period.

\section{MiAลี 131929}




\section{6}

UNIVERSITY OF CALIFORNIA LIBRARY 
